\title{
Primary Malignant Neoplasm
}

National Cancer Institute

\section{Source}

National Cancer Institute. Primary Malignant Neoplasm. NCI Thesaurus. Code C84509.

A malignant tumor at the original site of growth. 